\title{
ENGLISH TEACHERS' REFLECTIVE THINKING PRACTICE DURING THE ONLINE LEARNING AT SMAN 2 SINGARAJA
}

I Wayan Sastra Oka Paramartha ${ }^{1}$, I Putu Ngurah Wage Myartawan ${ }^{1}$, Ni Putu Astiti Pratiwi ${ }^{1}$

${ }^{1}$ Universitas Pendidikan Ganesha

Email: sastraokaparamartha@gmail.com

\begin{abstract}
The new learning system that is published by the Indonesian government as a prevention due to Covid-19 brings a new challenge for the teachers particularly in implementing $21^{\text {st }}$ century learning. Teachers are suggested to do a reflection toward the online learning that has been conducted to find out the teaching and learning process quality. This study is aimed at investigating the level of teachers' reflective thinking in which it was conducted in SMAN 2 Singaraja. There were two teachers involved in this study and the data were collected through the spreading of questionnaire and interview. The data were analyzed by using interactive data analysis to check the validity and reliability. The results showed that the awareness of the teacher in carrying out a process of reflection on learning during the online learning period. The efforts made by the English teacher at SMA N 2 Singaraja in improving the quality of learning both by discussing and innovating need to be used as an example for other teachers. In the future, of course, it is hoped that a better online learning process and learning objectives can be maximally achieved.
\end{abstract}

\section{Keywords: $21^{\text {st }}$ Century Learning, Online Learning, Reflective Thinking,}

\section{INTRODUCTION}

\subsection{Introduction}

Teachers are supposed to be a facilitator or director in helping students to connect their prior knowledge that the new knowledge that they learn in the classroom. It is a way for a teacher in building students' critical thinking and creativity in $21^{\text {st }}$ century. Choy et al (2017) states that teachers assist students when they face some problems during the learning process in which a good communication between students and teachers can be built through that process particularly in guiding process. On another hand, teachers are suggested to educate and motivate their students to work collaboratively in getting information, building a meaning, respecting the other strengths and weaknesses, taking a role, and adapting themselves properly. 
Therefore, teachers have a duty on assuring the students to be able to achieve the goals of $21 \mathrm{st}$ century learning.

Mayes \& Freitas De (2013) states that $21^{\text {st }}$ century learning is a reformed education aimed at equipping every students with the essential skills to face $21^{\text {st }}$ century challenges. Not all of teachers implement the this idea even many teachers still adapt a traditional teaching technique in which it affects students' interest in learning English. The incorporation 4C's elements are presented in this study due to $21^{\text {st }}$ century learning. Elola \& Oskoz (2010) argue that the integration of a collaboration aspect during learning activities helps students to build their ideas more effectively than studying alone. Students are allowed to share views and thoughts with their friends, and through this exchange of ideas, students may gain inspiration to be used in their writing. The collaboration also helps students in a group assess their accuracy in capitalization, spelling, grammar, and punctuation of the sentences they also constructed. Communication with their peers helps weaker students improve their writing skills while also talking to more competent students because they are more comfortable with their friends. In contrast, some students may feel shy or embarrassed to ask their teachers for help during classes(Hansen \& Imse, 2016).

The new learning design that is demanded by Indonesian Ministry of Education and Culture through Permendikbud Number 4 in 2020 about the implementation of education policies in the emergency period of the corona virus disease as known as COVID'19 outbreak stated that the learning process will be carried out from their respective homes. This regulation emerges a new challenge for the teachers considering that the learning process is usually conducted face to face. Teachers also face a struggle to serve students in remote area. It is stated that teachers are not ready to face the problem viewed from the reality of teachers' education program. The rapid change caused by covid-19 pandemic required teachers to master to master the digital competence era as what is required in twentieth-first century learning such as critical thinking skill, problem solving, networking, and collaborating.

In order to give an overview toward the online learning that is recently adapted in Indonesian education. A reflection is required to be conducted by the teachers. There is a number of indicators that is used to establish whether the teacher is already categorized as reflective teacher. Choy (2012) there are four indicators: ability to self-assess, awareness of how one learns, the influence of self-efficacy and belief, developing lifelong learning skill. Reflection is important part in teaching as the self-awareness of what the teachers do. Reflective thinking leads the teachers to feel responsible for their learning and affect the 
teachers' ability to question and reflect the learning process to get new perspective of learning process. Teachers need to focus on teaching activity from many perspectives such as; teachers require reflect on her/his students' thinking, understanding, interest, and the development of thinking. Therefore, by doing an evaluation it will provide the teachers an opportunity to increase the better understanding of the development of self-awareness (Flavian, 2016). It can allow the student to know how the English teachers see themselves as reflective practitioners by seeing the relationship between reflective thinking and the four aspects. Based on these definitions, this study aims to investigate which level of reflective thinking is the English teachers particularly in SMAN 2 Singaraja considering that the preliminary observation shows that SMAN 2 Singaraja is one of senior high school which implements online learning and suggests the teachers to do a reflection toward the teaching and learning process that has been conducted.

\subsection{Research questions}

Based on the research background above, the research question of this study is "Which level of reflective thinking is the English teachers in SMAN 2 Singaraja?"

\subsection{Significance of the study}

The significance of this study is viewed theoretically and practically as can be described as follows:

a) Theoretical Significant

The result of this study is expected to give an information about a positive contribution to further investigation and English teachers related to English teachers' reflective thinking during online learning.

\section{b) Practical Significant}

The result of this research is expected to give a practical contribution and inspire the teachers, the further researchers and the government

1. Teachers

The result of this study is expected to help English teachers in understanding and finding a solution to the problem of reflective thinking.

2. Further researcher

The result of this study is expected to be used as a helpful reference and guidance for the other researchers to find out research about reflective thinking in English teacher during online learning

3. The government

The result of this study is expected to be used as feedback on the undertaking of reflective thinking by English teachers during online learning in school in Bali, especially Buleleng. 


\section{METHOD}

This study was designed in the form of descriptive qualitative study in which the data were gained through the spreading of questionnaires. According to Sandeelowsky (2000), qualitative descriptive study is the method chosen when a direct description of a phenomenon is desired. Self-rated questionnaire was used as the instrument in the present study. The instrument consisted of four main reflective thinking skills which covered some indicators in each categorized skill to form some questions of the questionnaire. In order to check the content validity of questionnaire, two expert judges reviwed and score it. The Gregory formula was applied in analyzing the form and validity value interval was used to see the classification of the result of questionnaire. The study was conducted in SMAN 2 Singaraja where two English teachers involved as participants. After obtaining the needed data, three steps were applied to analyze the data based on Miles and Huberman (1994) as cited in (Ryan et al., 2009), namely data reduction, data display, and verification.

\section{FINDINGS AND DISCUSSION}

\subsection{Findings}

The aim of the present study was to find out the English teachers' reflective thinking in online learning. Thus, this section discussed the level of teacher reflective thinking. The data were obtained from the self-rated questionnaire. The results of self-rated questionnaire can be seen in Table 1.

Table 4.1 Result of Teachers' Perceived Knowledge of Their Reflective Thinking Practice

\begin{tabular}{|c|c|c|c|c|}
\hline Skills & No & Statements & Teacher 1 & Teacher 2 \\
\hline & 1 & $\begin{array}{l}\text { I need to find the most } \\
\text { effective strategies for my } \\
\text { students, considering their } \\
\text { characteristic and the } \\
\text { material. }\end{array}$ & 4 & 5 \\
\hline & 2 & $\begin{array}{l}\text { I get inspiration from my } \\
\text { colleagues for innovative } \\
\text { way of teaching. }\end{array}$ & 4 & 3 \\
\hline & 3 & $\begin{array}{l}\text { I evaluate my teaching } \\
\text { practice to see the } \\
\text { effectiveness. }\end{array}$ & 4 & 4 \\
\hline
\end{tabular}


$4 \quad$ I ask feedback from

students and colleagues to

reflect on what I present to

my class since I know it

will influence how my

students will behave toward

the lesson.

5 I never integrate my past

experience into my current teaching practice for better preparation.

$6 \quad$ I integrate my past experience into my current teaching practice for better preparation.

7 I think of what I had done

\section{Lifelong Learning Skill}

Self-Assessment Ability during my lessons so I can improve and discover myself to apply the knowledge towards the students so I can be a better teacher in the future

8 I generally get good 3 comments from students so I think I am doing quite well overall as a teacher.

9 I consider my students' feedback important as it will help me understand them better and it can be the indicator of the areas of my strengths and weaknesses

10 I make assumptions toward my colleagues' feedback and I learn from them.

11 I put my students' feedback 5 aside. I just need to teach them, not more.

12 I believe I can take care of 5 my needs as a teacher such as providing lesson plan, learning media, and also understanding the material that will be taught before 
transferring the knowledge

to students.

13 I try to look for the

connecting areas between

what and how I teach with

my life experiences.

14 I know the mistakes that I

made during my teaching

process can have an impact

on my students' lives.

15 I feel very anxious about students' feedback given to me, as it is obvious that they assess and judge me as a person.

\section{Self-Belief}

16 In order to improve my

teaching, I try to think

about what I teach my

students in terms of my own area of discipline.

17 I have a set of practices

which I am comfortable with, although the feedback I receive from students and my colleagues swill help me further enhance those practices.

18 My self-quality and the set of my teaching practices will be influenced by my beliefs.

19 I do not know my behaviour

Teaching Awareness will ultimately be controlled by what I believe about myself as a teacher towards students' lives.

20 I try to reflect on what I do during my lessons so I can enrich the strategies I use with new and more effective ones. 
Table 1 shows the level of teacher reflective thinking. After adding up the scores of the 20 statements above, the researcher calculated the total score. The total score for T1 is 76 and 87 for the T2 which means that English teachers in SMA N 2 Singaraja are categorized as advanced teachers in implementing their reflective thinking. It can see on the table T1 perceived that she was good in reflecting her teaching and learning process during online learning with the total point of 76 and also T2 perceived that she was good in reflecting her teaching and learning process during online learning with the total point of 87 . Both of the teachers perceived themselves as advanced in reflecting their learning process with the average score of 81.5. This advanced level of reflective thinking implementation was seen from the implementation the four skills of reflective thinking. From the results of the questionnaire, the teacher has tried to find the best teaching strategy for students and has carried out an evaluation process of their teaching practice. Teachers also often discuss with colleagues to get inspiration for more innovative teaching methodologies. Thus, it can be said that the teacher is aware of a reflection process in order to improve the quality of learning.

Asking feedback from the students and colleagues in order to reflect on what they present to the class since they know it will influence how their students will behave toward the lesson, the T1 and T2 chose often (4) that they are evaluate their teaching practice to see the effectiveness. Furthermore, in terms of integrating their past experiences into their current teaching practice for better preparation, T1 choose often (4) and T2 choose always (5) integrate experience into other less current teaching and learning practices, and teach students the best preparations. Then, teachers improve and discover themselves to apply the knowledge towards the students and can be a better teacher in the future. T1 chose often (4) and T2 choose always (5), it was the way to realize the practice of lifelong learning skill. T1 and T2 choose often (4) that they consider students' feedback important as it will help the teachers understand the students better and it can be the indicator of the areas of my strengths and weaknesses. Moreover, deliberating feedbacks derived from the colleagues T1 and T2 choose sometimes (3). Regarding from the implementation of self-belief, T1 always (5) believe that they can take care of their needs as teachers such as providing lesson plan, learning media, and also understanding the material that will be taught before transferring the knowledge to students, $\mathrm{T} 2$ choose often for that. T1 and T2 choose often (4) on self-rated questionnaire that they try 
to look for the connecting areas between what and how they teach with their life experiences. T2 always (5) know the mistakes that they made during their teaching process can have an impact on students' lives but T1 sometimes (3) know about that. In addition to teachers' selfbelief, T1 rare (2) feel very anxious about students' feedback given to them and T2 choose sometimes (3) fell anxious about students' feedback. T1 and T2 choose often (4) about set of practices which teacher comfortable with, although the feedback receive from students and colleagues will help the teachers further enhance those practices. Regarding from the implementation of teaching awareness, T1 chooses always (5) to teachers beliefs will influence self-quality and set of their teaching practice and often (4) from T2. T1 choose always (5) and $\mathrm{T} 2$ often (4) that they try to reflect on what they do during the lessons, they can enrich the strategies that they use with new and more effective ones.

\subsection{Discussion}

Considering the existence of teacher reflective thinking, Ratminingsih et al., (2017) state that reflecting a teaching process is really important in order to carry out a better process. This could be started from planning, teaching implementation until the assessment process. Furthermore, Zahid and Khanam (2019) found that after conducting reflective practice, the skills and performance of teachers were significantly improved. In addition, Yildirim (2017) states that the reflective thinking process requires teachers to act systematically, continuously examining and researching to develop solutions. Teachers ask themselves questions, analyse their performance, and determine how to increase performance by rearranging their goals. Teachers consider other colleagues' criticisms and use them constructively. They have a positive attitude towards their profession and are helpful towards other colleagues. They do not avoid taking responsibility in the educational environment, act frankly by thinking continuously and purposefully, use perceived problems as a catalyst for vocational improvement, and apply these changes in the educational environment.

In terms of integrating their past experiences, Adadan and Oner (2018) state that in reassessing experiences, teachers have to identify such elements as an association (relationships between ideas), integration (relationship of new insights with existing knowledge), validation (internal consistency testing), and appropriation (making the new insights our own in a personal way). The process of reflective thinking is generally considered continuous and cyclic, in which difficult experiences lead to reflection and ultimately to new interpretations and understandings. In the present study, teacher realize the practice of lifelong learning skill. Lee et al. (2007) stated that there are three levels of depth included quality criteria for reflective thinking. The first is to remind preservation teachers of their experiences 
concerning their perceptions, to describe the others, and to interpret them. The second is rationalization in which teachers seek to establish relationships and interpret their experiences with reasons between various aspects of their experiences. The third level is a representation in which teachers examine their experiences from several perspectives to modify their experiences in the future.

In self-assessment, the teachers can be said that they are the advanced level of teacher's reflective thinking when the teacher always think about their experience and improve their teaching performance by listen to their students feedback, also make a different perspective to learn about their experience (Choy et al., 2017). Reflective thinking is a constructivist process in which an individual creates his/her own unique intellectual products. With reflective thinking, the individual comes to a conclusion by associating the ideas about an information unit or subject in a consecutive way (Egmir \& Ocak, 2020). The teacher can improve their teaching by get the new ideas from students' feedback and make their teaching more interactive.

Regarding to the self-belief, Pfitzner-Eden (2016) state that individuals form selfefficacy beliefs by interpreting information regarding their own capabilities. This information stems from four sources: mastery experiences, vicarious experiences, verbal persuasion, and physiological and affective states. Mastery experiences provide information about one's successes, but also failures. Generally, successful experiences increase self-efficacy beliefs, while experiences of failure lower them. Therefore, in self-belief the teacher can said that they are the advanced level of teachers' reflective thinking when the teacher perceive relation with their student to their ability in teach, social interaction will be important thing how student learn in the classroom (Choy et al., 2017). Moreover, Balta (2018) with the increase in the beliefs which is the process is important in learning, As the preservice teachers' beliefs that ability to learn can be developed over time increased, their tendencies of continuous and intentional thinking, open-mindedness, interrogative and effective teaching, teaching responsibility, and looking professional increased as well. Ugur et al., (2015) suggest that teachers should be aware of their weakness during teaching process. By knowing their weaknesses, teachers can evaluate and improve themselves. Perceive teachers became more aware of their assumptions, values, and beliefs when their teaching practices were reflected (Farrell, 2008).

Related to the implementation of teaching awareness, Adadan and Oner (2018) state that reflective thinking as active and conscious processing and careful analysis of discrepancies between one's goals, experiences and observations, in order to identify new ways of 
understanding oneself as a teacher, both collectively and individually. In this respect, the knowledge and ability of teachers to plan, monitor and regulate their own teaching thinking, understanding and knowledge appear to be the main aspect of reflective thinking. Choy et al.(2017) state that the teacher can be said that they are the advanced level of teachers' reflective thinking when the teacher consider their performance in the classroom with their experiences to improve their teaching skill in the next performance, they listen to their students feedback to pre-service teachers becoming more motivated, proficient, and effective in the classroom. In addition, Yildirim (2017) argue that teachers who think reflectively contribute to raising productive and highly qualified individuals, which is a need for society, by passing on this skill to their students. They use different strategies to teach their students by got the feedback from their students in the classroom

From the explanation above, Lifelong learning skill, Self-Assessment, Self-belief, and Teaching Awareness are the components that use to know the advanced level of teacher's reflective thinking (Choy et al., 2017). The teachers can be said that they are advanced teacher in lifelong learning skill when they can learn from their supervisor feedback and improve their teaching performance by carry out continuous assessment and evaluations of their teaching strategies and the influences they have on student learning. Then, in self-assessment when the teacher always think about their experience and improve their teaching performance by listen to their students feedback, also make a different perspective to learn about their experience. Therefore, in self-belief when the teacher perceive relation with their student to their ability in teach, social interaction will be important thing how student learn in the classroom. The last is teaching awareness, the teacher consider their performance in the classroom with their experiences to improve their teaching skill in the next performance, they listen to their students' feedback to pre-service teachers becoming more motivated, proficient, and effective in the classroom.

\section{CONCLUSIONS}

\subsection{Conclusion}

The present study concludes that the are four types of reflective thingking skills, namely lifelong learning skill, self-assessment, self-belief, and teaching awareness. Lifelong learning skill covers the learning experience and continuous assessment. Next, self-assessment covers teacher and students' feedback in improving skill. Then, self-belief covers the social interaction in the learning process. The last is teaching awareness. It considers the reflection of teachers' performance to next better performance. These four component skills show that the teacher 
has advanced level of reflective thinking. It guides the teacher to have better performance in the learning process.

\subsection{Suggestions}

Some suggestions are formulated to some parties, namely teachers and other researchers. For the teachers, they are expected to continuously carry out the process of reflective thinking even though they are advance practitioners. This is in line with the concept of reflective thinking in whihc the process is always repeated and in accordance with the concept of lifelong learning. For the other researchers, the further study is recommended to conduct a reflective thinking study with a larger number of participants so that deeper data can be obtained. Besides that, further study is encouraged to identify the reflective thinking process from the institutional point of view. Some benefits can be obtained by both teachers and other researchers. The teachers will get better performance along with the reflection done by the teacher. Then, the other reseachers also get new point of view in conducting reflective thinking research.

\section{REFERENCES}

Adadan, E., \& Oner, D. (2018). Examining preservice teachers' reflective thinking skills in the context of web-based portfolios: The role of metacognitive awareness. Australian Journal of Teacher Education, 43(11), 26-50. https://doi.org/10.14221/ajte.2018v43n11.2

Balta, E. E. (2018). Reflective thinking tendencies and epistemological beliefs in terms of learning styles. International Journal of Higher Education, 7(6), 106-117. https://doi.org/10.5430/ijhe.v7n6p106

Choy, S. C., Yim, J. S. C., \& Tan, P. L. (2017). Reflective thinking among preservice teachers: A Malaysian perspective. Issues in Educational Research, 27(2), 234-251.

Egmir, E., \& Ocak, , Ijlal. (2020). The Relationship between Teacher Candidates' Critical Thinking Standards and Reflective Thinking Skills. International Journal of Progressive Education, 16(3), 156-170. https://doi.org/10.29329/ijpe.2020.248.12

Farrell, T. S. C. (2008). Brief reflective practice in the professional development of teachers of adult English language learners. CAELA Network, October, 1-4.

Lee, P. S., Tsang-Hsiung, L., \& Tsai, C. (2007). Applying Web-Enabled Problem-Based 
Learning and Self-Regulated Learning to Enhance Computing Skills of Taiwan' $\mathrm{s}$ Vocational Students: a Quasi-Experimental Study of a Short-Term Module. The Electronic Journal of E-Learning, 5(2), 147-156.

Pfitzner-Eden, F. (2016). Why do i feel more confident? Bandura's sources predict preservice teachers' latent changes in teacher self-efficacy. Frontiers in Psychology, 7(OCT), 1-16. https://doi.org/10.3389/fpsyg.2016.01486

Ratminingsih, N. M., Artini, L. P., \& Padmadewi, N. N. (2017). Incorporating self and peer assessment in reflective teaching practices. International Journal of Instruction, 10(4), 165-184. https://doi.org/10.12973/iji.2017.10410a

Ugur, H., Constantinescu, P. M., \& Stevens, M. J. (2015). Self-awareness and personal growth: Theory and application of bloom's taxonomy. Egitim Arastirmalari - Eurasian Journal of Educational Research, 60, 89-110. https://doi.org/10.14689/ejer.2015.60.6

Yildirim, T. (2017). An Examination on Geography Teachers' Reflective Thinking Tendencies. International Journal of Higher Education, 6(6), 78. https://doi.org/10.5430/ijhe.v6n6p78

Zahid, M., \& Khanam, A. (2019). Effect of Reflective Teaching Practices on the Performance of Prospective Teachers. Turkish Online Journal of Educational Technology - TOJET, $18(1), 32-43$. 